\title{
Do CEO Demographics Explain Cash Holdings in SMEs?
}

\author{
Raf Orens \\ Anne-Mie Reheul
}

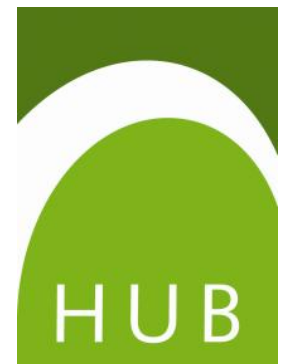




\title{
Do CEO Demographics Explain Cash Holdings in SMEs?
}

\author{
Raf Orens ${ }^{\mathrm{a}}$ \\ Anne-Mie Reheul ${ }^{b}$ \\ ${ }^{a}$ Lessius (K.U.Leuven) - Department of Business Studies \\ Korte Nieuwstraat 33, 2000 Antwerpen, Belgium \\ raf.orens@lessius.eu
}

Phone: + 32 (0)3 2011860

${ }^{b}$ Anne-Mie Reheul,

Hogeschool-Universiteit Brussel

Warmoesberg 26, 1000 Brussels, Belgium.

annemie.reheul@hubrussel.be

Phone: + 32 (0)2 6098868

Fax: + $32(0) 22101222$ 


\title{
Do CEO Demographics Explain Cash Holdings in SMEs?
}

\begin{abstract}
This study examines the idiosyncratic manager-specific influence on a corporate cash policy. Although traditional economic theories such as trade-off theory and agency theory have already contributed to a deeper understanding of corporate cash policy, we examine whether the integration of Hambrick and Mason's (1984) upper echelons theory (UET) into these traditional theories provides additional power in explaining corporate cash holdings. We contend that social, psychological and cognitive characteristics of CEOs, proxied by a number of CEO demographics, affect the level of importance that CEOs (and shareholders) attach to the economic arguments provided by the traditional theories, in turn affecting cash policy. We test our hypotheses using a sample of Belgian privately held SMEs. Controlling for a number of operational and financial variables, our results illustrate that CEOs have a considerable influence on corporate cash holdings. In line with most of the hypotheses our principal findings suggest that longer tenured CEOs, older CEOs and CEOs with experience in a single industry are more concerned with the precautionary motive of cash and less concerned with the opportunity cost of cash, giving rise to higher cash levels compared to shorter tenured CEOs, younger CEOs and CEOs with experiences outside the current industry. We thus reveal that cash policy in Belgian privately held SMEs reflects the natural tendencies of CEOs. Since cash policy affects shareholder value, it is important for shareholders to consider the demographics of present or new CEOs, and to understand their associated inclinations concerning cash policy.
\end{abstract}

Keywords: agency theory; cash policy; SME; trade-off theory; upper echelons theory

\section{Introduction}

Prior literature documents that firms hold a reasonable proportion of their assets as cash and cash equivalents, but shareholders have to be concerned that CEOs retaining excess levels of cash might distort overall shareholder value (Harford, 1999). Prior research attributes cross-sectional differences in corporate cash holdings to traditional economic theories, such as the trade-off theory (Opler et al., 1999), the financial hierarchy theory (Myers \& Majluf, 1984) and the agency (free cash flow) theory, which all assume rational behaviour (Jensen 1986). Empirical studies using these theories reveal that firm, industry and institutional characteristics such as for example a firm's corporate governance structure (e.g. Chen \& Chuang, 2009; Huan et al., 2011; Kusnadi, 2011), growth opportunities (Opler et al., 1999; García-Teruel \& Martinez-Solano, 2008), firm diversification (Subramaniam et al., 2011) or legal system (e.g. Dittmar et al., 2003; Fereira \& Vilela, 2004) determine cross-sectional differences in cash reserves. Next to this traditional approach, an emerging body of finance literature considers 
bounded rationality and associated behaviours/perceptions of decision-makers as attributes of financial phenomena like stock returns, trading activity and corporate finance (Subrahmanyam, 2007). This stream of literature investigates managerial attributes (cognitive ability), behaviours (overconfidence) and perceptions (with regard to valuation) and link them to corporate financial decisions related to capital structures and corporate investments (Baker \& Wurgler, 2002, Malmendier \& Tate, 2005). With regard to cash holdings, Chang \& Noorbakhsh (2009) and Ramirez \& Tadesse (2009) reveal that cultural values, perceptions and inclinations influence the level of corporate cash holdings in different countries.

We contribute to this recent stream of finance literature by examining whether the integration of Upper Echelons Theory (UET) into the traditional economic theories improves the explanation of crosssectional differences in corporate cash holdings. UET argues that decision makers are characterized by bounded rationality and therefore also make decisions on the basis of their cognitive, social and psychological characteristics. Organizational processes and decisions thus include a behavioural component that reflects the idiosyncrasies of decision makers (Hambrick \& Mason, 1984). According to UET the cognitive, social and psychological characteristics of CEOs can be proxied by demographics like tenure, education, background, age and gender (Hambrick, 2007). The extant UET literature relates CEO demographics to various organizational processes and outcomes, such as innovation (Kitchell, 1997), R\&D spending (Barker \& Mueller, 2002), internationalization (Herrmann, 2002), corporate financial disclosure (Bamber et al., 2010), strategy formation (Gibbons \& O'Connor, 2005) and firm performance (Weinzimmer, 1997). However, Carpenter et al. (2004) made a call in the UET literature to focus on understudied corporate processes. We respond to this call by examining whether a CEO can place his distinctive marks on his firm's cash policy. Our study relates to Bertrand \& Schoar (2003) who, in a sample of large listed firms, observe an idiosyncratic manager-specific influence of individual managers on corporate decisions such as cash holdings.

Based on the combined insights from UET and the traditional economic theories, we investigate whether CEO demographics (i.e. tenure, age, experience in other industries and education) are reflected in corporate cash holdings in a sample of small and medium-sized enterprises (SMEs). We conduct this study on a sample of 203 Belgian manufacturing SMEs. The CEO specific data are collected using the survey approach. We opt for a setting of SMEs since CEOs from these firms have more discretion in their decision to hold cash compared to CEOs from large listed firms (GarcíaTeruel \& Martínez-Solano, 2008).

The paper proceeds as follows. Section 2 presents our theoretical framework and develops our hypotheses. Section 3 elaborates on our research design. Section 4 presents the results of the empirical analyses, and finally, section 5 comprises a discussion and conclusion of this study. 


\section{Theoretical framework and hypothesis development}

We examine whether the integration of UET into the traditional economic theories provides additional power in explaining corporate cash holdings. Traditional economic theories provide rational economic arguments in (dis)favour of both low and high cash levels. We propose that cash policy also depends on decision-makers' perceived or subjective importance attached to these alternative economic arguments. This argumentation is based on the principle of bounded rationality, in which UET is grounded. As our theoretical framework builds further on the traditional economic theories, we review these theories in section 2.1. This section also motivates why the trade-off theory has a stronger impact on a firm's cash policy for our sample firms compared to the agency theory. In section 2.2 we develop our hypotheses by integrating insights from the UET with the traditional economic theories. We also elaborate on the presence of CEO discretion in our dataset.

\subsection{Traditional theories of cash holdings}

The extant literature relies on a number of traditional economic theories to explain variations in cash holdings, primarily the trade-off theory and the agency theory.

The trade-off theory states that the amount of cash retained in a firm is based on the trade-off between the benefits and the costs of holding cash. According to Opler et al. (1999), firms are able to receive two major benefits of holding cash. First, firms are able to reduce transaction costs related to raising external funds. The liquid assets can be used to finance operating activities and investments decreasing the costs of external financing. Second, cash holdings are also considered as a buffer against unexpected events (Opler et al., 1999). In addition, having certain cash levels reduces the likelihood of financial distress, especially for those firms with more volatile cash flows. On the other hand, investing in cash also reveals some costs. Holding cash has an opportunity cost since lower returns are obtained compared to productive investments.

The agency literature contends that large free cash flows increase the power of CEOs. When the firm has sufficient funds to finance its projects internally, CEOs avoid the monitoring when applying for new funds from the financial markets. This may result in projects that suit managerial interest, but not shareholder interest. Excessive amounts of cash, especially in profitable firms with low investment opportunities, can be detrimental to the shareholders if these resources are invested in value decreasing projects (Jensen, 1986; Opler et al., 1999; Chang \& Noorbakhsh, 2009). Consequently, cash levels are found to be lower in situations of important agency conflicts between managers and shareholders. First, shareholders prevent the risk of managers making value decreasing acquisitions by requiring dividend pay, subsequently decreasing cash positions. Second, managers avoid the accumulation of 
excess cash in this circumstance since it attracts the attention of shareholders resulting in proxy contents and leading to the increased probability of executive turnover and cash distributions to shareholders (Faleye, 2004). Good governance on the other hand, implying low agency conflicts, is able to mitigate the managerial self interest in holding excess cash, in which circumstance higher cash levels are revealed (Harford et al., 2008). The objective of corporate governance is hence to ensure that firms maintain appropriate levels of cash and to find a balance between the agency costs of overinvestment and the expected return of holding cash for profitable investments. Another important type of agency conflict in privately held SMEs is the agency conflict associated with debt (Berger \& Udell, 2003). The financial hierarchy theory (or pecking order theory) considers the agency idea of information asymmetry to posit that firms prefer to finance investments with resources internally generated before resorting to debt providers, since in the presence of information asymmetry firms have more difficulties to obtain funds and/or have to pay more interests (Myers \& Majluf, 1984). In situations of large agency conflicts (high information asymmetry) with debt providers, managers hold higher levels of cash for flexibility reasons (Opler et al., 1999).

In the hypothesis development section we integrate UET into the traditional economic theories in order to derive hypotheses. Since our dataset consists of privately held SMEs active in manufacturing industries of the old economy, we primarily focus on the trade-off theory to set hypotheses. Chen (2008) contends that trade-off theory plays a more important role for firms that belong to the old economy. The agency theory is of lower importance in our dataset for the following reasons. The large majority of the SMEs in our dataset are family firms where management and ownership coincide, implying that the conflicts between managers and shareholders are less strong than in large, listed firms, which was the main focus of prior research. Even in the case of minority shareholders, the latter group demonstrate trust and perceive fewer agency problems as it is often assumed that founders/owners act in the firm's best interest, given their painstaking efforts invested in the firm and given their concern with the family legacy (Kuan et al., 2011). Our dataset also consists of a smaller number of non-owner managed SMEs, but their ownership structure is concentrated. Belgium is characterized by very strong ownership concentration (Peeters \& Bogaert, 2005); demonstrating levels that are much higher than the US case for example (Anderson \& Hammadi, 2009). In Belgium, SMEs are typically owned by one or a few major shareholders: families (in the case of family firms as mentioned before), corporate owners or banks. The control by majority shareholders is thus likely to be very effective, lowering agency conflict. The second largest declared shareholder in Belgian firms only owns a small percentage of a firm's shares (Anderson \& Hammadi, 2009). Consequently, minority shareholders will probably be less concerned with potential agency conflicts because of their higher wealth diversification. In addition, agency conflicts with debtholders are of lower importance as the SMEs in our dataset belong to the old - rather stable - economy and are less likely to make very risky investments compared to new tech firms (Chen, 2008). Furthermore, Anderson et al. (2003) 
observe that family firms, constituting the bulk of our dataset, cope with lower agency costs of debt. The undiversified portfolio of private family firm owners implies a long term view of the owners through which valuable trust can be built between firm and lenders, leading to lower agency costs of debt and more favourable lending conditions (Ang, 1992)

As agency theory is of lesser importance than trade-off theory in our dataset, we integrate UET primarily with the trade-off theory to set hypotheses, and only secondary with the agency theory, principally only where UET makes a very explicit link with this theory.

\subsection{Hypothesis development}

According to UET managerial decision making is to a large extent the outcome of top managers' cognitive, psychological and social frames due to bounded rationality, to multiple and conflicting goals, to differing preferences and to varying aspiration levels (Hambrick \& Mason, 1984). Organizations are a reflection of their top managers (Carpenter et al., 2004). An important concept within UET is CEO discretion or latitude of freedom. CEO discretion is the degree to which CEOs can put their distinctive cognitive, social and psychological marks on organizational processes and decisions (Hambrick \& Finkelstein, 1987). If CEO discretion is lacking, contextual factors rather than executive characteristics will be reflected in organizational processes/outcomes and no association will be found between CEO characteristics and organizational processes/outcomes. If discretion is present, a CEO is able to affect organizational processes and to contribute to a firm's outcome. CEO discretion is influenced by amongst other environmental conditions (e.g. hostility versus munificence) and organizational factors (e.g. board, ownership) (Hambrick, 2007).

An important prerequisite for conducting this study is that the CEOs in our dataset have sufficient levels of discretion and are able to put their distinctive marks into cash policy. The following paragraph demonstrate that our research population consisting of privately held SMEs, primarily family firms, enables a lot of CEO discretion.

First, in SMEs CEOs are found to have wider discretion than in large firms. In SMEs CEOs are often the sole decision makers concerning corporate policies (Miller et al., 1982). Other members of the top management team (TMT) and boards of directors only have a secondary role in decision-making in SMEs, especially in mature SMEs, which is the case in our study, where TMTs and active boards are often absent (Van Gils, 2005). Second, agency conflicts between managers and owners are likely to be low in family firms, which allow CEOs to use high levels of cash to their own discretion (Harford et al., 2008). Third, the firms in our sample operate in the old economy. Old economy firms are less likely to experience large cash flow volatility compared to new economy firms, are characterized by less risky investments compared to new tech firms, and face fewer challenges to obtain external 
finance (Chen, 2008). Based on these arguments, which indicate munificence or at least a low degree of hostility (Hambrick, 2007), CEOs from old economy firms might have more discretion to hold a certain level of cash.

As CEOs in our dataset have a substantial amount of discretion concerning the level of cash retained, we propose in line with UET that their cognitive, social and psychological characteristics affect their decision on the level of cash they retain. The UET stipulates that CEO demographic characteristics are adequate proxies to measure the CEO's underlying cognitive, psychological and social characteristics (Hambrick, 2007). For the purpose of our study, we consider following CEO demographics: CEO tenure, $\mathrm{CEO}$ age, $\mathrm{CEO}$ experience in other industries and $\mathrm{CEO}$ education. Based on UET, we posit that CEO cognitive, social and psychological characteristics, proxied by the CEO demographics, influence corporate cash policy by affecting the extent to which CEOs (and shareholders) are concerned with the arguments proposed by primarily the trade-off theory and secondary the agency theory.

We develop hypotheses concerning CEO tenure and CEO age simultaneously as these constructs are strongly correlated with each other (Damanpour \& Schneider, 2006). Using arguments grounded in UET we expect longer tenured and older CEOs to attach more value to the precautionary and flexibility role of cash, to grant less value to the opportunity cost of cash and to be associated with lower agency conflicts as perceived by shareholders.

First, the UET reveals that longer tenured and older CEOs are more risk averse than shorter tenured and younger CEOs (Barker \& Mueller, 2002; Kor 2006). Consequently, longer tenured and older CEOs tend to hold larger levels of cash in order to hedge against future, undesirable events. In addition, risk averse CEOs tend to have a higher preference for (safe) internal funding over (more risky) external funding. Hence, we assume that longer tenured and older CEOs are more conservative and more concerned with the precautionary motive of cash, resulting in higher cash levels compared to shorter tenured and younger CEOs. This expectation is in line with Bertrand \& Schoar (2003) who already evidenced a positive association between CEO age and cash holdings for a sample of large firms.

Second, based on UET we presume that longer tenured CEOs pay less attention to the opportunity cost of holding excess levels of cash, which may lead them to hold more cash than shorter tenured CEOs. This presumption is grounded in studies documenting the presence of regular patterns in the life cycle of CEOs (Hambrick \& Fukutomi, 1991; Miller, 1991). New CEOs have to gain knowledge about the organisation and the environment in which the firm operates (Richard et al., 2009), are more likely to consider several alternatives, have a more external focus, and are more open to fresh ideas, change and 
experimentation (Hambrick et al., 1993) than long tenured CEOs. As short tenured CEOs identify more investment opportunities we suggest that they will be more aware of the opportunity cost of not investing cash in profitable projects and expect lower cash levels with shorter tenured CEOs. As tenure increases, CEOs become more confident that they will not be replaced and commit to their earlier strategies hereby refusing to collect and analyse external information and refusing to pursue change (Finkelstein \& Hambrick, 1996; Miller \& Shamsie, 2001). Due to their risk aversion, inertia and lack of external focus we posit that long tenured CEOs will be less concerned with the opportunity cost of cash.

Third, longer tenured and older CEOs have more power to influence the selection of board members and to constitute personal relationships with directors compared to shorter tenured and younger CEOs (Westphal \& Zajac, 1995; Finkelstein \& Hambrick, 1996). Longer tenured and older CEOs also demonstrate more legitimacy in the eyes of internal and external stakeholders ${ }^{1}$ (Miller, 1991) which mitigates agency conflicts as perceived by directors and shareholders. Consequently, such CEOs are allowed to use higher cash levels to their own discretion.

Based on these arguments, we posit the following hypotheses:

\section{Hla: Cash holdings are positively associated with a CEO's tenure \\ HIb: Cash holdings are positively associated with a CEO's age}

CEO experience is another UET variable. The UET contends that managerial decision making is also affected by the extent to which executives have other experiences. As both CEO experience in the same industry and CEO executive tenure cause similar psychological, social and cognitive tendencies (Finkelstein \& Hambrick, 1996), we focus on CEO experience in other industries. On the basis of UET we expect that CEOs with more years of experience from outside industries reckon more with the opportunity cost of cash. CEOs who have more experience from outside industries possess broader knowledge bases and broader modes of thinking and operating compared to CEOs who have spent their career in the same industry (Raskas \& Hambrick, 1992). Consequently, this experience should help the CEOs to identify emerging opportunities. Executives with a higher diversity in experience have a more positive underlying attitude towards change and innovation (Dearborn \& Simon, 1958), whereas executives who have spent their career in the same industry are more committed to industry conventions, "recipes" and established ways of operating (Hambrick et al., 1993). Industry experience also expands CEOs' professional networks (Richard et al., 2009), which might increase CEOs'

\footnotetext{
${ }^{1}$ This reasoning may seem contradictory with UET's proposition that performance of CEOs reduces with their tenure (Finkelstein \& Hambrick, 1990, Miller, 1991, Walters et al., 2007). However, Norburn \& Birley (1988) and Thomas et al. (1991) reveal that the predispositions of long tenured CEOs, such as well-developed repertoires, stability and internal experience can be beneficial in more stable industries like the ones included in this study.
} 
awareness of opportunities to invest in productive investments instead of keeping large amounts of cash. Following these arguments, we contend that CEOs with experience in other industries view more opportunities to invest cash resources.

According to UET, CEO experience is unrelated with CEO power and hence we do not make a proposition combining UET with agency theory. We hypothesize that:

H2: Cash holdings are negatively associated with a CEO's experience in other industries

Besides CEO tenure, age and experience, the level of CEO education is also an important UET variable. It may seem unlikely that educational experiences would affect managerial decisions since top executives typically are many years beyond their formal education. Yet a significant body of research suggests that CEO education is reflected in the characteristics of their organizations, through the association of education with a wide array of cognitive, psychological and social characteristics. CEO education is associated with a higher capacity for information processing (Schroder et al., 1967), a higher level of open-mindedness, higher receptivity to innovation (Becker, 1970), higher boundary spanning, higher tolerance for ambiguity and higher integrative complexity (Dollinger, 1984). These observed associations have been found robust and stable, also after controlling for CEO age and industrial setting (Wiersema \& Bantel, 1992). We expect higher educated CEOs to be associated with lower cash levels for the following reasons.

First, as higher educated CEOs are less risk averse and better informed about the external environment (Dollinger, 1984; Schroder et al., 1967), we posit that they will be less concerned with the precautionary motive of cash. Second, as higher educated CEOs are more open to new ideas, changes and investment opportunities (Wiersema \& Bantel, 1992; Wally \& Baum, 1994; Barker \& Mueller, 2002), we posit that these CEOs are aware of the opportunity cost of cash. Hence, higher educated CEOs are more likely to spend their cash resources in profitable investments compared to lower educated CEOs as their external focus identifies more investment opportunities and as they better realize that productive investments provide higher returns compared to cash.

According to UET, CEO experience is unrelated with CEO power and hence we do not make a proposition combining UET with agency theory. We posit that:

H3: Cash holdings are negatively associated with a CEO's educational level.

\section{Research method}


In order to test our hypotheses, we collect data from a sample of Belgian manufacturing SMEs. The following sections detail the sample selection procedure, the survey instrument employed, the measurement of the variables and the research method.

\subsection{Sample selection}

The research population consists of Belgian (Flemish) SMEs with between 15 and 250 full time equivalent employees, belonging to four industry-codes within manufacturing and in business for at least five years. The four selected industries (manufacture of furniture, of synthetic products, of metal constructions, and of machinery for general use) are the largest ones within the SME sector. By selecting firms from specific industry codes and regions, we are able to control for the influence of industry, technology, and culture on cash policy. Applying these selection criteria yields a population of 948 firms.

These firms received a questionnaire in order to collect information about the CEO demographics and the control variable Environmental Uncertainty (EU). The questionnaires were addressed to each firm's CEO. Following Dillman (2000), we implement following three steps during our survey: (i) initial mailing, (ii) first follow-up, and (iii) second follow-up. We received 138 usable responses immediately. The two follow-ups resulted in an additional 82 usable responses. In total, we obtained 220 usable responses, representing a response rate of $23.21 \%$. This response rate is satisfactory and comparable to the response rates reported in other mail-survey studies of small firms (Dennis, 2003). After excluding missing answers and corresponding financial variables, we withhold 203 observations.

In order to detect non-response bias, a two-step analysis is conducted. First, we compare respondents with non-respondents in terms of firm size, leverage, profitability, liquidity and cash holdings. Chisquare tests reveal no significant differences between respondents and non-respondents with respect to these variables. We control the main construct measures (i.e. the variables relating to the CEO) for dissimilarity between the immediate respondents and the respondents to the follow-up surveys. Independent sample t-tests and chi square tests reveal no differences between both groups. These analyses allow us to conclude that non-response bias is not a major concern in this sample.

\subsection{Measurement instruments}

Cash holdings as dependent variable is measured as the ratio between cash and cash equivalents to total assets less cash and cash equivalents (Opler et al., 1999; Harford et al., 2007) ${ }^{2}$. Since the survey is conducted in 2006, we compute the level of cash holdings at year-end 2006. In addition, we compute the average level of cash holdings at year-ends 2005 and 2006 which proxy for the average

\footnotetext{
${ }^{2}$ We also scale with total assets instead of net assets, and get similar research findings.
} 
level of cash holdings during the year 2006. Since industry might be a significant factor in the level of cash holdings (Harford et al., 2007), we compute an industry adjusted measure of a firm's cash holdings. We compute the median cash holdings within each of the four industries included in our study and subtract the corresponding industry median cash holdings from each firm's level of cash holdings. A higher industry-adjusted cash holding indicates how much excess (if positive) or less (if negative) cash a firm holds compared to the industry's median value.

The research variables include the CEO demographics collected from the survey. In the questionnaire, CEO age is measured as a categorical variable including three classes: younger than 35 year, between 35 and 50 year, and more than 50 year. These classes correspond with the classes used in Damanpour and Schneider (2006). We create dummy variables for each class and include in the regression equation the dummy variable indicating whether the CEO is between 35 and 50 year and whether the CEO is older than 50 years. We expect a positive sign for both indicator variables suggesting that younger CEOs (less than 35 years) are less likely to hold excess cash levels compared to the older CEOs. CEO Tenure is the natural logarithm of one plus the number of years that the CEO holds its current position in the firm. CEO Other Experience is measured as the natural logarithm of one plus the number of years that the CEO has been appointed in companies from other industries. $C E O$ Education is a dummy variable with the value of one when a CEO obtained at least a degree in higher education and zero otherwise.

Firm's level of cash holdings is regressed on the research variables together with some control variables (i.e. firm size, cash flow generation, liquidity, financial leverage, environmental uncertainty and industry membership). Firm Size is the natural logarithm of the total assets. We expect a negative association between cash holdings and firm size since larger firms benefit from economies of scale of holding cash that is used for their normal activities (Mulligan, 1997). In addition, larger firms have lower financial constraints (Whited, 1992; Fazzari \& Petersen, 1993), have lower levels of information asymmetry (Jordan et al., 1998; Berger et al., 2001) and are to lower extent vulnerable to financial distress (Rajan \& Zingales, 1995; Titman \& Wessels, 1998). Cash Flow Generation is computed as the ratio between cash flows to total assets. In case of information asymmetry, firms prefer to fund themselves with internally generated resources instead of borrowing these funds (Myers \& Majluf, 1984). Hence, we assume a positive association between cash levels and cash flows, consistent with Opler et al. (1999) and García-Teruel \& Martínez-Solano (2008). Liquidity is defined as the difference between current assets (less cash and cash equivalents) and current liabilities scaled by total assets. We expect a negative association between liquidity and cash holdings (Chen, 2008). Financial leverage is measured as the ratio between long and short bank debts and total assets. Prior literature finds a negative association between cash holdings and leverage since the costs of funds used to invest in liquid assets rise as leverage increases (Baskin, 1987; García-Teruel \& Martínez-Solano, 2008). 
Environmental uncertainty tends to be an important attribute of a corporate cash policy (Ramirez \& Tadesse 2009). Environmental uncertainty implies the inability to accurately assess the external environment of the organization or the future changes that might occur in that environment. Higher levels of environmental uncertainty make it difficult for managers to make accurate predictions about the market (Milliken, 1987). Consequently, a high level of environmental uncertainty is more likely to result in fear $^{3}$ for potential financial distress caused by unexpected losses. Potential cash shortage could force managers to raise funds on unfavourable terms or to liquidate other assets at large discount. To overcome this situation, CEOs operating under a high level of environmental uncertainty may decide to hold larger levels of cash at their disposal. Environmental uncertainty is measured on the basis of the CEOs' responses on factors that capture this concept ${ }^{4}$. Finally, we control for industry influence by inserting industry dummies in the regression equation.

Due to collinearity between CEO tenure and CEO age, we opt to include each variable separately in the regression equations. Cash holding is either the level of cash at year 2006 or the average level of cash from year-ends 2005 and 2006. The dependent and control variables are winsorized at $1 \%$ and $99 \%$ level to mitigate the influence of outliers.

\section{Results}

Table 1 exhibits descriptive statistics of the research variables and reports that, on average, CEO tenure is 13 years and the average years of experience in another industry is about 4 years. We further note that $80 \%$ of the respondents have a degree in higher education. With respect to industry membership, $33 \%$ of respondents operate in the metal structures manufacturing industry. The remaining three industries each represent about $22 \%$ of respondents. The average deviation of a firm's cash holdings from industry mean is about 7\%. Untabulated findings illustrate that on average cash and cash equivalents represent $16 \%$ of a firm's total assets. We also notice that the large

\footnotetext{
${ }^{3}$ To a higher or lower extent, depending on a CEO's tolerance for ambiguity for example.

${ }^{4}$ To capture environmental uncertainty, we use an instrument based on Gordon \& Narayanan (1984) still widely used in the recent literature (Abdel-Kader \& Luther, 2008). Respondents rate on a 5 point Likert scale ranging from 1 (="completely predictable") to 5 (="completely unpredictable") the extent to which each of the following eight environmental elements are unpredictable: market activities of competitors, needs and tastes of customers, actions of suppliers, production technologies, government regulation and policy, economic environment, industrial relations, and deregulation/globalization. Based on a factor analysis, the ratings on only six items (excluding the two factors relating to the unpredictability of customers and suppliers) are averaged to arrive at an overall EU index. Internal consistency is assessed with the Cronbach's $\alpha$ coefficient and corresponds with a value of 0.66 . This meets the cutoff value of 0.6 (Hair et al., 1998).
} 
majority of responding SMEs are small (67\% count less than 50 FTE employees) and mature (90\% have been in business for more than 10 years).

\section{Insert Table 1 here}

Table 2 presents the correlation matrix. This matrix allows us to observe univariate associations between our research variables. We find that firms with a longer CEO tenure and with an older CEO (more than 35 years) are more likely to hold more cash reserves. Cash holding is negatively associated with firms employing CEOs having experiences in other industries. These results are in line with predictions. The level of education is unrelated with cash holdings. With respect to the control variables, Table 3 exhibits that firms with higher cash flows and with lower bank debts have higher levels of cash. A strong positive correlation exists between cash levels and environmental uncertainty. The association between cash holdings and firm size is only marginally significant, but is probably inherent to the sample selection consisting of a homogenous group of small entities that do not differ very much in size (García-Teruel \& Martínez-Solano, 2008).

Insert Table 2 here

In order to examine the association between cash holdings and a set of research and control variables, we run OLS regressions. Table 4 reports several models. Model 1 and Model 2 incorporate CEO tenure, CEO experience in other industries and CEO education and associate these variables with the two proxies for firm's cash holdings. Model 3 and Model 4 are similar to the previous models, except that CEO tenure is replaced with CEO age. In order to control for heteroscedasticity, significance levels are adjusted to reflect White's correction of the standard errors.

Insert Table 3 here

The OLS regression results correspond with the univariate statistics and are also consistent across the proxy used as the dependent variable. Findings illustrate a positive coefficient for CEO tenure indicating that firms tend to keep more cash when the CEO's tenure is longer (Model 1 and 3). Both dummy variables related with $C E O$ age have a positive association with the level of cash holdings (Model 2 and 4), revealing that older CEOs tend to hold higher levels of cash. These results confirm $\mathrm{H} 1 \mathrm{a}$ and $\mathrm{H} 1 \mathrm{~b}$. Concerning CEO experience, our findings reveal that CEOs with more experience in other industries are less likely to hold excess levels of cash compared to CEOs who are only familiar with a single industry. Hence, these results allow us to confirm H2. Finally, cash holdings are found to be unrelated with the level of education, which is not in line with H3. The coefficients of the control variables are in line with prior literature, except for firm size. Firms with more cash flows, 
lower debt levels and lower levels of working capital hold higher levels of cash. Firm size is unrelated with the level of cash holdings. We also observe a positive coefficient for the variable $E U$, indicating that firms are more likely to retain cash when their CEOs have less confidence in future economic development.

\section{Robustness checks}

We modify our regression equations to investigate whether we obtain the same results. Table 4 reports regression results of these sensitivity analyses, but only with the average cash holdings as dependent variable. We obtain similar results when cash levels of 2006 are included as a dependent variable.

\section{Insert Table 4 here}

First, we estimate our regression equations for a sample of CEOs having sufficient years of CEO tenure. At the start of their tenure, CEOs typically gain a lot of knowledge by means of experimentation and change (Miller \& Shamsie, 2001). Only after a certain period, typically three years (Finkelstein \& Hambrick 1996, p. 83), CEOs increasingly commit themselves to earlier strategies, refuse to collect and analyse external information and refuse to pursue change (Miller \& Shamsie, 2001). Since the UET focus is on the negative side of CEO tenure, this theory is better captured by focusing on those CEOs that are appointed for at least three years. Taking into account this consideration, we regress the CEO demographics and control variables on cash holdings for a set of firms where the CEO is appointed for at least 3 years. The results in Table 4 (Model 1 and 2) exhibit a positive and significant association between CEO tenure and cash holdings, and between CEO age and cash holdings. CEO education is unrelated with cash holdings. The coefficient for CEO experience in other industries is negative and significant. These results are similar to prior results.

Second, we examine whether the CEO variables present the same results controlling for the impact of corporate governance on cash holdings (Harford et al., 2008; Kuan et al., 2011). To capture board structure we include the following three variables that were collected from the financial statements and from Graydon, a company providing business information: board size (number of directors), percentage of outside directors ${ }^{5}$ (ratio of outside director to total directors) and CEO duality (dummy variable that equals 1 when the chairman of the board is also the CEO). Prior studies document that board structure impacts cash holdings. For instance, outside directors increase firm's network to raise funds, which lowers the need to retain excess cash (Ozkan \& Ozkan, 2004). Kuan et al. (2011) document a positive association between CEO duality and cash holding. If CEO and chairman are the

\footnotetext{
${ }^{5}$ A director is classified as outsider if he/she does not belong to the firm's management or the latter's relatives.
} 
same person, the CEO may hold more cash in order to pursue private interests at the expense of shareholders (Shakir, 2009; Kuan et al., 2011). Model 3 and 4 in Table $4^{6}$ illustrate that none of the governance variables has a significant effect on cash holdings ${ }^{7}$. Consistent with our prior results, longer tenured CEOs tend to hold larger cash reserves and CEOs with experience in other industries tend to keep lower levels of cash. CEO age shows a positive association with cash holding.

\section{Discussion and conclusion}

Traditional finance theories like the trade-off theory and the agency theory provide economic arguments to explain cash holdings and adopt a rational economic view. The contribution of our study is to consider the (subjective) importance attached to these alternative economic arguments to explain cash levels. The latter is captured by means of the CEOs' cognitive, social and psychological characteristics, which is grounded in the Upper Echelons Theory (UET) (Hambrick \& Mason, 1984). This theory attributes well defined behaviours and inclinations to CEOs with certain cognitive, social and psychological characteristics, and posits that the latter characteristics can be validly proxied by CEO demographics (e.g. tenure, education,...). Our study builds further on the recent stream of behavioural finance studies that depart from decision-makers' bounded rationality in explaining financial decisions (Subrahmanyam, 2007). In particular, we integrate insights of UET into the traditional finance theories; primarily the trade-off theory given the old economy- and family-oriented setting of our study.

We conduct our study using a sample of 203 CEOs of Flemish SMEs as it is generally acknowledged that CEOs in SMEs are often sole decision-makers and thus have high discretion in determining cash policy (Van Gils, 2005). Our study reveals that in addition to the most prominent financial and operational variables explaining cash policy, CEO demographics add power in models explaining cash holdings. In line with the expectations, we reveal that longer tenured and older CEOs retain higher cash levels compared to shorter tenured and younger CEOs. Combining UET with trade-off theory, our findings suggest that longer tenured and older CEOs demonstrate a higher aversion towards risk and change, giving rise to a higher importance attached to the precautionary role of cash and a lower importance to the opportunity cost of cash, resulting in higher cash levels. Our results confirm Bertrand and Schoar (2008) observing that older CEOs prefer to hold more cash compared with younger CEOs. Our findings can also be clarified by combining UET with agency theory. UET posits that longer tenured and older CEOs demonstrate more legitimacy in the eyes of internal and external stakeholders (Miller 1991), which mitigates agency conflicts as perceived by directors and

\footnotetext{
${ }^{6}$ As private limited liability companies in Belgium are not legally required to have boards of directors, the sample is parsed of the 42 SMEs concerned for the analyses in Table 4.

${ }^{7}$ A potential explanation for these insignificant findings is the high prevalence of 'paper' boards among mature SMEs (Van Gils, 2005).
} 
shareholders, in turn allowing longer tenured and older CEOs to use higher cash levels to their own discretion. Consistent with our hypothesis, we find that CEOs with experience in only a single industry hold more cash than CEOs with experience in different industries. In harmony with UET and the trade-off theory, a higher diversity in experience is associated with a more positive underlying attitude towards change and innovation (Dearborn and Simon 1958), which increases CEOs' awareness of opportunities to invest and leads them to be more concerned with the opportunity cost of cash, resulting in lower cash levels. Similar to Bertrand and Schoar (2008), but inconsistent with our expectations, we observe an insignificant association between CEO education and cash holdings. A potential explanation for the insignificant finding is that more educated managers tend to pursue longterm development and do not invest in current projects which can generate lower returns than longterm projects. This strategy accumulates free cash flows and increases cash holdings.

The findings of our study are of practical importance for shareholders since CEOs tend to hold excess cash levels, causing opportunity costs, which is detrimental to shareholder value. Therefore, it is useful to shareholders to know the cash practices associated with current or potential new leaders' demographics. Shareholders should for example be aware that longer tenured and older CEOs and CEOs with experience in only a single industry tend to hold higher levels of cash, increasing the risk to miss opportunities and lowering shareholder value. Shareholders should judge whether these tendencies are acceptable, given the broader organizational context, and should try to modify these tendencies if necessary.

The present study is subject to a number of limitations, which provide avenues for future research. A first set of limitations relates to the measurement of the CEO demographics. With regard to CEO education we consider the level of education, not the type of education. Future research could examine whether type of education, e.g. more business-oriented or more technical-oriented, is significant in explaining cash policy. With regard to CEO experience we only consider the years of experience in outside industries, and do not focus on functional experience (marketing, sales, general management,...). Future studies could explore whether different kinds of functional experiences affect CEO behaviour with regard to cash policy in a different way. Second, our research population is restricted to industrial SMEs in the old economy. We are unable to generalize our results to SMEs in other industries. Future research can examine whether a CEO's impact on cash policy is similar in commercial SMEs and service SMEs or in high tech firms. 


\section{Tables}

Table 1

DESCRIPTIVE STATISTICS (N=203)

\begin{tabular}{|c|c|c|c|c|}
\hline & Min & Max & Mean & Std. dev. \\
\hline \multicolumn{5}{|l|}{ Dependent variables } \\
\hline Cash $_{t}$ & -0.11 & 0.87 & 0.07 & 0.20 \\
\hline $\mathrm{Cash}_{\text {avg }}$ & -0.11 & 0.88 & 0.07 & 0.19 \\
\hline \multicolumn{5}{|l|}{ Independent variables } \\
\hline \multicolumn{5}{|l|}{ CEO demographics } \\
\hline CEO tenure & 0.50 & 45.00 & 13.37 & 10.36 \\
\hline CEO age $<35$ & 0 & 1 & 0.10 & 0.30 \\
\hline CEO age35_50 & 0 & 1 & 0.47 & 0.50 \\
\hline CEO age $>50$ & 0 & 1 & 0.43 & 0.50 \\
\hline CEO other industry experience & 0.00 & 30.00 & 3.99 & 6.83 \\
\hline CEO education & 0 & 1 & 0.80 & 0.40 \\
\hline \multicolumn{5}{|l|}{ Control variables } \\
\hline $\operatorname{SIZE}_{\mathrm{t}-1}$ & 5.72 & 12.78 & 8.47 & 1.09 \\
\hline CFLOW $_{\mathrm{t}-1}$ & -0.37 & 0.31 & 0.10 & 0.10 \\
\hline $\mathrm{LIQ}_{\mathrm{t}-1}$ & -0.61 & 0.67 & 0.13 & 0.24 \\
\hline FLEV $_{t-1}$ & 0.00 & 0.40 & 0.07 & 0.10 \\
\hline $\mathrm{EU}$ & 1.17 & 4.50 & 3.09 & 0.50 \\
\hline Ind_281 & 0 & 1 & 0.33 & 0.47 \\
\hline Ind_252 & 0 & 1 & 0.22 & 0.41 \\
\hline Ind_292 & 0 & 1 & 0.23 & 0.42 \\
\hline Ind_361 & 0 & 1 & 0.22 & 0.43 \\
\hline
\end{tabular}

Notes:

This table provides descriptive statistics for the variables Cash $\mathrm{t}_{\mathrm{t}}$ industry adjusted cash and cash equivalents at year 2006 scaled by total assets less cash and cash equivalents; Cash ${ }_{\text {avg }}$ : industry adjusted average cash and cash equivalents at year-ends 2005 and 2006 scaled by total assets less cash and cash equivalents; CEO tenure: number of years that the CEO is appointed in the firm; CEO age <35: dummy variable representing 1 when the CEO is less than 35 year; CEO age35_50: dummy variable representing 1 when the CEO is between 35 and 50 year old; CEO age >50: dummy variable representing 1 when the CEO is more than 50 year; CEO other industry experience: number of years that the CEO has experience in other industries; CEO education: dummy variable representing 1 when the $\mathrm{CEO}$ obtained a degree in higher education; SIZE $_{\mathrm{t}-1}$ : natural $\log$ of total assets in 2005; $\mathrm{CFLOW}_{\mathrm{t}-1}$ : cash flow to total assets in 2005; $\mathrm{LIQ}_{\mathrm{t}-1}$ : current assets minus current liabilities scaled by total assets in 2005; $\mathrm{FLEV}_{\mathrm{t}-1}$ : long- and short-term debt to total assets in 2005; EU: Environmental uncertainty; Ind_281: manufacture of metal construction (nacebel industry code 281); Ind_252: manufacture of synthetic products (nacebel industry code 252), Ind_292: manufacture of machinery for general use (nacebel industry code 292); Ind_361: manufacture of furniture (nacebel industry code 361). 
Table 2

PEARSON CORRELATION MATRIX (N=203)

\begin{tabular}{|c|c|c|c|c|c|c|c|c|c|c|c|c|c|}
\hline & 1 & 2 & 3 & 4 & 5 & 6 & 7 & 8 & 9 & 10 & 11 & 12 & 13 \\
\hline 1. Cash $_{t}$ & 1.000 & & & & & & & & & & & & \\
\hline 2. Cash $_{\text {avg }}$ & $0.955^{* * *}$ & 1.000 & & & & & & & & & & & \\
\hline 3. CEO tenure & $0.199^{* * *}$ & $0.192^{* * *}$ & 1.000 & & & & & & & & & & \\
\hline 4. CEO age $<35$ & -0.086 & $-0.118^{* *}$ & $-0.353^{* * *}$ & 1.000 & & & & & & & & & \\
\hline 5. CEO age35_50 & -0.018 & -0.004 & $-0.215^{* * *}$ & $-0.319^{* * * *}$ & 1.000 & & & & & & & & \\
\hline 6. CEO age $>50$ & 0.071 & 0.076 & $0.435^{* * *}$ & $-0.294^{* * * *}$ & $-0.812^{* * *}$ & 1.000 & & & & & & & \\
\hline $\begin{array}{l}\text { 7. CEO o.i. } \\
\text { experience }\end{array}$ & $-0.166^{* * *}$ & $-0.192^{* * *}$ & $-0.265^{* * *}$ & -0.065 & -0.071 & 0.111 & 1.000 & & & & & & \\
\hline 8. CEO education & -0.064 & -0.048 & $-0.263^{* * *}$ & 0.010 & 0.054 & -0.060 & $0.236^{* * *}$ & 1.000 & & & & & \\
\hline 9. SIZE $_{t-1}$ & $-0.103^{*}$ & $-0.099^{*}$ & $-0.117^{*}$ & -0.025 & $-0.106^{*}$ & $0.123^{*}$ & 0.012 & $0.184^{* * *}$ & 1.000 & & & & \\
\hline 10. CFLOW & $0.202^{* * *}$ & $0.176^{* * *}$ & 0.099 & 0.010 & 0.004 & -0.010 & -0.100 & -0.096 & 0.025 & 1.000 & & & \\
\hline 11. $\mathrm{LIQ}_{\mathrm{t}-1}$ & 0.005 & -0.048 & $0.163^{* *}$ & -0.001 & -0.115 & $0.116^{*}$ & 0.009 & 0.016 & $0.140^{\text {*** }}$ & $0.268^{* * * *}$ & 1.000 & & \\
\hline 12. FLEV $_{t-1}$ & $-0.289^{* * *}$ & $-0.332^{* * *}$ & $-0.166^{* *}$ & 0.094 & 0.053 & -0.111 & 0.072 & 0.039 & 0.032 & $-0.162^{* *}$ & $-0.208^{* * * *}$ & 1.000 & \\
\hline 13. EU & $0.182^{* * * *}$ & $0.165^{* * *}$ & 0.070 & 0.022 & 0.018 & -0.031 & -0.108 & $-0.154^{* *}$ & -0.070 & 0.087 & -0.059 & -0.075 & 1.000 \\
\hline
\end{tabular}

This table reports the Pearson correlation coefficients between Cash: industry adjusted cash and cash equivalents at year 2006 scaled by total assets less cash and cash equivalents; Cash $_{\text {avg }}$ industry adjusted average cash and cash equivalents at year-ends 2005 and 2006 scaled by total assets less cash and cash equivalents; CEO tenure: natural logarithm of one plus the number of years that the CEO is appointed in the firm; CEO age<35: dummy variable representing 1 when the CEO is less than 35 year; CEO age35_50: dummy variable representing 1 when the CEO is between 35 and 50 year old; CEO age>50: dummy variable representing 1 when the CEO is more than 50 year; CEO o.i.(other industry) experience: natural logarithm of one number of years that the CEO has experience in other industries; CEO education: dummy variable representing 1 when the CEO obtained a degree in higher education; SIZE $\mathrm{E}_{\mathrm{t}-1}$ : natural log of total assets in 2005; $\mathrm{CFLOW}_{\mathrm{t}-1}$ : cash flow to total assets in 2005 ; $\mathrm{LIQ}_{\mathrm{t}-1}$ : current assets minus current liabilities scaled by total assets in 2005 ; FLEV $\mathrm{t}_{-1}$ : longand short-term debt to total assets in 2005; EU: Environmental uncertainty

${ }^{* * * * * * *},{ }^{*}$ indicates statistical significance at the $1 \%, 5 \%$ and $10 \%$ levels respectively (one tailed test) 
Table 3

REGRESSION RESULTS ON THE ASSOCIATON BETWEEN

CEO DEMOGRAPHICS AND CASH POLICY (N=203)

\begin{tabular}{|c|c|c|c|c|}
\hline Variables & $\begin{array}{r}\text { Model 1 } \\
\text { Cash }_{\mathrm{t}} \\
\end{array}$ & $\begin{array}{r}\text { Model 2 } \\
\text { Cash }_{\mathrm{t}} \\
\end{array}$ & $\begin{array}{r}\text { Model } 3 \\
\text { Cash }_{\text {avg }}\end{array}$ & $\begin{array}{r}\text { Model } 4 \\
\text { Cash }_{\text {avg }} \\
\end{array}$ \\
\hline Intercept & $\begin{array}{r}0.087 \\
(0.096)\end{array}$ & $\begin{array}{r}0.163 \\
(0.096)^{*}\end{array}$ & $\begin{array}{r}0.083 \\
(0.089)\end{array}$ & $\begin{array}{r}0.137 \\
(0.088)\end{array}$ \\
\hline CEO tenure & $\begin{array}{r}0.034 \\
(0.016)^{* *}\end{array}$ & & $\begin{array}{r}0.031 \\
(0.016)^{* *}\end{array}$ & \\
\hline CEO age35_50 & & $\begin{array}{r}0.050 \\
(0.034)^{*}\end{array}$ & & $\begin{array}{r}0.062 \\
(0.028)^{* * *}\end{array}$ \\
\hline CEO age $>50$ & & $\begin{array}{r}0.076 \\
(0.036)^{* * * *}\end{array}$ & & $\begin{array}{r}0.088 \\
(0.031)^{* *}\end{array}$ \\
\hline CEO o.i. exp & $\begin{array}{r}-0.016 \\
(0.009)^{* *}\end{array}$ & $\begin{array}{r}-0.024 \\
(0.010)^{* * * *}\end{array}$ & $\begin{array}{c}-0.020 \\
(0.008)^{* * * *}\end{array}$ & $(0.009)^{-0.028}$ \\
\hline CEO education & $\begin{array}{r}0.028 \\
(0.044)\end{array}$ & $\begin{array}{r}0.020 \\
(0.044)\end{array}$ & $\begin{array}{r}0.035 \\
(0.042)\end{array}$ & $\begin{array}{r}0.028 \\
(0.041)\end{array}$ \\
\hline SIZE $_{t-1}$ & $\begin{array}{r}-0.007 \\
(0.010)\end{array}$ & $\begin{array}{r}-0.011 \\
(0.011)\end{array}$ & $\begin{array}{r}-0.006 \\
(0.009)\end{array}$ & $\begin{array}{r}-0.010 \\
(0.010)\end{array}$ \\
\hline CFLOW $_{t-1}$ & $\begin{array}{r}0.335 \\
(0.128)^{* * *}\end{array}$ & $\begin{array}{r}0.333 \\
(0.126)^{* * *}\end{array}$ & $\begin{array}{r}0.286 \\
(0.116)^{* * *}\end{array}$ & $\begin{array}{r}0.287 \\
(0.113)^{* * *}\end{array}$ \\
\hline $\mathbf{L I Q}_{\mathrm{t}-1}$ & $\begin{array}{r}-0.078 \\
(0.058)\end{array}$ & $\begin{array}{r}-0.067 \\
(0.056)\end{array}$ & $\begin{array}{c}-0.123 \\
(0.054)^{* *}\end{array}$ & $\begin{array}{c}-0.113 \\
(0.052)^{* *}\end{array}$ \\
\hline FLEV $_{t-1}$ & $\begin{array}{r}-0.498 \\
(0.116)^{* * *}\end{array}$ & $\begin{array}{c}-0.497 \\
(0.115)^{* * * *}\end{array}$ & $\begin{array}{r}-0.590 \\
(0.105)^{* * * *}\end{array}$ & $(0.104)^{-0.581}$ \\
\hline EU & $\begin{array}{r}0.172 \\
(0.073)^{* * *}\end{array}$ & $\begin{array}{r}0.178 \\
(0.073)^{* * * *}\end{array}$ & $\begin{array}{r}0.135 \\
(0.073)^{* *}\end{array}$ & $\begin{array}{r}0.140 \\
(0.073)^{* *}\end{array}$ \\
\hline $\begin{array}{l}\text { Industry dummies } \\
\text { Adiusted } \mathbf{R}^{2}\end{array}$ & $\begin{array}{r}\text { Yes } \\
13.4 \%\end{array}$ & $\begin{array}{r}\text { Yes } \\
12.5 \%\end{array}$ & $\begin{array}{r}\text { Yes } \\
16.2 \%\end{array}$ & $\begin{array}{r}\text { Yes } \\
16.1 \%\end{array}$ \\
\hline F-value & $3.833^{* * * *}$ & $3.461^{* * * *}$ & $4.543^{* * *}$ & $4.291^{* * *}$ \\
\hline $\mathbf{N}$ & 203 & 203 & 203 & 203 \\
\hline
\end{tabular}

Notes:

This table report OLS regression results including the following variables $\mathrm{Cash}_{\mathrm{t}}$ : industry adjusted cash and cash equivalents at year 2006 scaled by total assets less cash and cash equivalents; Cash $_{\text {avg: }}$ : industry adjusted average cash and cash equivalents at year-ends 2005 and 2006 scaled by total assets less cash and cash equivalents; CEO tenure: natural logarithm of one plus the number of years that the CEO is appointed in the firm; CEO age35_50: dummy variable representing 1 when the CEO is between 35 and 50 year old; CEO age>50: dummy variable representing 1 when the CEO is more than 50 year; CEO o.i.(other industry) experience: natural logarithm of one number of years that the CEO has experience in other industries; CEO education: dummy variable representing 1 when the CEO obtained a degree in higher education; $\mathrm{SIZE}_{\mathrm{t}-1}$ : natural $\log$ of total assets in 2005; CFLOW $\mathrm{t}_{\mathrm{t}-1}$ : cash flow to total assets in 2005; $\mathrm{LIQ}_{\mathrm{t}-1}$ : current assets minus current liabilities scaled by total assets in 2005; FLEV $_{\mathrm{t}-1}$ : long- and short-term debt to total assets in 2005; EU: Environmental uncertainty and industry dummies

The table exhibits the beta coefficient and the White corrected standard error between brackets. ${ }^{* * * *},{ }^{* *},{ }^{*}$ indicates statistical significance at the $1 \%, 5 \%$ and $10 \%$ levels respectively (one tailed test). 
Table 4

SENSITIVITY ANALYSES ON THE ASSOCIATON BETWEEN

CEO DEMOGRAPHICS AND CASH POLICY $(\mathrm{N}=203)$

\begin{tabular}{|c|c|c|c|c|}
\hline Variables & $\begin{array}{r}\text { Model 1 } \\
\text { Cash }_{\text {avg }} \\
\end{array}$ & $\begin{array}{r}\text { Model } 2 \\
\text { Cash }_{\text {avg }} \\
\end{array}$ & $\begin{array}{r}\text { Model 3 } \\
\text { Cash }_{\text {avg }} \\
\end{array}$ & $\begin{array}{r}\text { Model } 4 \\
\text { Cash }_{\text {avg }}\end{array}$ \\
\hline Intercept & 0.026 & 0.107 & 0.114 & 0.161 \\
\hline & $(0.103)$ & $(0.101)$ & (0.117) & (0.119) \\
\hline CEO tenure & $\begin{array}{r}0.051 \\
(0.025)^{* *}\end{array}$ & & $\begin{array}{r}0.032 \\
(0.020)^{* *}\end{array}$ & \\
\hline CEO age35_50 & & $\begin{array}{r}0.095 \\
(0.036)^{* * *}\end{array}$ & & $\begin{array}{r}0.059 \\
(0.036)^{* *}\end{array}$ \\
\hline CEO age $>50$ & & $\begin{array}{r}0.120 \\
(0.038)^{* * * *}\end{array}$ & & $\begin{array}{r}0.086 \\
(0.038)^{* * *}\end{array}$ \\
\hline CEO o.i. exp & $\begin{array}{r}-0.022 \\
(0.009)^{* * *}\end{array}$ & $\begin{array}{r}-0.031 \\
(0.010)^{* * *}\end{array}$ & $\begin{array}{r}-0.024 \\
(0.010)^{* * * *}\end{array}$ & $\begin{array}{r}-0.031 \\
(0.011)^{* * *}\end{array}$ \\
\hline CEO education & $\begin{array}{r}0.042 \\
(0.045)\end{array}$ & $\begin{array}{r}0.033 \\
(0.043)\end{array}$ & $\begin{array}{r}0.011 \\
(0.050)\end{array}$ & $\begin{array}{r}0.006 \\
(0.049)\end{array}$ \\
\hline $\mathbf{S I Z E}_{\mathrm{t}-1}$ & $\begin{array}{r}-0.006 \\
(0.010)\end{array}$ & $\begin{array}{r}-0.010 \\
(0.011)\end{array}$ & $\begin{array}{r}-0.006 \\
(0.012)\end{array}$ & $\begin{array}{l}-0.009 \\
(0.013)\end{array}$ \\
\hline CFLOW $_{t-1}$ & $\begin{array}{r}0.324 \\
(0.135)^{* * * *}\end{array}$ & $\begin{array}{r}0.300 \\
(0.134)^{* * *}\end{array}$ & $\begin{array}{r}0.310 \\
(0.138)^{* * *}\end{array}$ & $\begin{array}{r}0.303 \\
(0.136)^{* * *}\end{array}$ \\
\hline $\mathbf{L I Q}_{\mathrm{t}-1}$ & $\begin{array}{r}-0.135 \\
(0.061)^{* *}\end{array}$ & $\begin{array}{r}-0.111 \\
(0.059)^{* *}\end{array}$ & $\begin{array}{r}-0.166 \\
(0.068)^{* * * *}\end{array}$ & $\begin{array}{c}-0.161 \\
(0.067)^{* * *}\end{array}$ \\
\hline FLEV $_{t-1}$ & $\begin{array}{r}-0.581 \\
(0.127)^{* * * *}\end{array}$ & $\begin{array}{r}-0.602 \\
(0.128)^{* * * * *}\end{array}$ & $\begin{array}{r}-0.656 \\
(0.139)^{* * * *}\end{array}$ & $\begin{array}{r}-0.660 \\
(0.139)^{* * * *}\end{array}$ \\
\hline $\mathbf{E U}$ & $\begin{array}{r}0.160 \\
(0.077)^{* *}\end{array}$ & $\begin{array}{r}0.157 \\
(0.076)^{* *}\end{array}$ & $\begin{array}{r}0.044 \\
(0.076)\end{array}$ & $\begin{array}{r}0.057 \\
(0.073)\end{array}$ \\
\hline B_SIZE & & & $\begin{array}{r}0.001 \\
(0.011)\end{array}$ & $\begin{array}{r}0.001 \\
(0.011)\end{array}$ \\
\hline P_OUTDIR & & & $\begin{array}{r}0.009 \\
(0.040)\end{array}$ & $\begin{array}{l}-0.011 \\
(0.042)\end{array}$ \\
\hline DUALITY & & & $\begin{array}{r}0.007 \\
(0.028)\end{array}$ & $\begin{array}{r}0.010 \\
(0.029)\end{array}$ \\
\hline Industry dummies & Yes & Yes & Yes & Yes \\
\hline Adjusted $\mathbf{R}^{2}$ & $15.6 \%$ & $14.9 \%$ & $14.5 \%$ & $14.4 \%$ \\
\hline F-value & $4.018^{* * *}$ & $3.609^{* * *}$ & $2.939^{* * *}$ & $2.825^{* * *}$ \\
\hline $\mathbf{N}$ & 180 & 180 & 161 & 161 \\
\hline
\end{tabular}

Notes:

This table reports OLS regression results on the sensitivity analyses. Model 1 and 2 investigate the impact of CEO demographics on cash holding in the assumption that the CEO is appointed for at least 3 years. Model 3 and 4 include additional controls for the quality of corporate governance in the sample firms, i.e. B_SIZE: the number of directors on the board; P_OUTDIR: proportion of outside directors on the Board and DUALITY: dummy variable representing the value of 1 when the CEO is also chairman of the Board. The remaining variables are Cash $_{\text {avg: }}$ industry adjusted average cash and cash equivalents at year-ends 2005 and 2006 scaled by total assets less cash and cash equivalents; CEO tenure: natural logarithm of one plus the number of years that the CEO is appointed in the firm; CEO age35_50: dummy variable representing 1 when the CEO is between 35 and 50 year old; CEO >50: dummy variable representing 1 when the CEO is more than 50 year; CEO o.i.(other industry) experience: natural logarithm of one number of years that the CEO has experience in other industries; CEO education: dummy variable representing 1 when the CEO obtained a degree in higher education; $\mathrm{SIZE}_{\mathrm{t}-1}$ : natural $\log$ of total assets in 2005; $\mathrm{CFLOW}_{\mathrm{t}-1}$ : cash flow to total assets in 2005; LIQ $_{\mathrm{t}-1}$ : current assets minus current liabilities scaled by total assets in 2005; FLEV $\mathrm{t}$ :-1: long- and shortterm debt to total assets in 2005; EU: Environmental uncertainty and industry dummies.

The table exhibits the beta coefficient and the White corrected standard error between brackets. ${ }^{* * *},{ }^{* *},{ }^{*}$ indicates statistical significance at the $1 \%, 5 \%$ and $10 \%$ levels respectively (one tailed test). 


\section{References}

Abdel-Kader, M. and Luther, R. (2008) The impact of firm characteristics on management accounting practices: a UK-based empirical analysis. The British Accounting Review 40(1), 2-27.

Anderson, R.W. and Hamadi, M. (2009) Large powerful shareholders and cash holding. LSF Research Working Paper Series, $\mathrm{N}^{\circ}$. 09-04, available online: http://www.lsf.lu/eng/Research/Working-Papers/2009.

Anderson, R.., Mansi, S. \& Reeb, D. (2003) Founding family ownership and the agency cost of debt. Journal of Financial Economics 68, 263-285.

Ang, J.S. (1992). On the theory of finance for privately held firms. Journal of Small Business Finance 1(3), 185-203.

Baker, M. and Wurgler, J. (2002) Market timing and capital structure. Journal of Finance 57(1), 1-32.

Bamber, L.S., Jiang J. and Wang, I.Y. (2010) What's my style? The influence of top managers on voluntary corporate financial disclosure. The Accounting Review 85(4), 1131-1162.

Barker III, V.L. and Mueller, G. (2002) CEO Characteristics and firm R\&D spending. Management Science 48(6), 782-801.

Baskin J. (1987) Corporate liquidity in games of monopoly power. Review of Economics and Statistics 69, 312-319.

Becker, M.H. (1970) Sociometric location and innovativeness: Reformulation and extension of the diffusion model. American Sociological Review 35, 367-304.

Berger, A., Klapper, F. and Udell, G. (2001) The ability of banks to lend informationally opaque small business. Journal of Banking and Finance 25, 2127-2167.

Berger, A. N. and Udell, G. F. (2003) The institutional memory hypothesis and the procyclicality of bank lending behaviour. Finance and Economics Discussion Series 2003-02, Board of Governors of the Federal Reserve System (U.S), 1-38. 
Bertrand, M. and Schoar, A. (2003) Managing with style: the effect of managers on firm policies. The Quarterly Journal of Economics 118(4), 1169-1208.

Carpenter, M.A., Geletkanycz, M.A. and Sanders, W.G. (2004) Upper echelons research revisited: Antecedents, elements, and consequences of top management team composition. Journal of Management 30(6), 749-778.

Chang, K. and Noorbakhsh, A. (2009) Does national culture affect international corporate cash holdings? Journal of Multinational Financial Management 19, 323-342.

Chen, Y-R and Chuang, W-T. (2009). Alignment or entrenchment? Corporate governance and cash holdings in growing firms. Journal of Business Research 62, 1200-1206.

Chen, Y-R. (2008) Corporate governance and cash holdings: listed new economy versus old economy firms. Corporate Governance 16(5), 430-442.

Damanpour, F. and Schneider, M. (2006) Phases of adoption of innovation in organizations: effects of environment, organization and top managers. British Journal of Management 17(3), 215-236.

Dearborn, D. C. and Simon, H. A. (1958) Selective perceptions: A note on the departmental identification of executives. Sociometry 21, 140-144.

Dennis, Jr., W.J. (2003) Raising response rates in mail surveys of small business owners: results of an experiment. Journal of Small Business Management 41(3), 278-295.

Dillman, D.A. (2000). Mail and Internet surveys: The tailored design method. 2nd Edition. John Wiley $\&$ Sons, New York.

Dittmar, A., Mahrt-Smith, J. and Servaes, H. (2003) International corporate governance and corporate cash holdings. Journal of Financial and Quantitative Analysis 36(1), 111-133.

Dollinger, M.J. (1984). Environmental boundary spanning and information processing effects on organizational performance. Academy of Management Journal, 27(2), 351-368.

Faleye, O. (2004) Cash and corporate control. Journal of Finance 59, 2041-2060. 
Fazzari, S.M. and Petersen, B. (1993) Working capital and fixed investment: new evidence on financing constraints. Rand Journal of Economics 24, 328-342.

Ferreira, M.A. and Vilela, A. (2004) Why do firms hold cash? Evidence from EMU countries. European Finance Management 10, 295-319.

Finkelstein, S., and Hambrick, D.C. (1996) Strategic leadership: top executives and their effects on organizations. St Paul: West Publishing Company, Minneapolis.

García-Teruel, P.J. and Martínez-Solano, P. (2008) On the determinants of SME cash holdings: evidence from Spain. Journal of Business Finance \& Accounting 35(1-2), 127-149.

Gibbons, P.T. and O'Connor, T. (2005) Influences on strategic planning processes among Irish SMEs. Journal of Small Business Management 43(2), 170-186.

Gordon, L.A. and Narayanan, V.K. (1984) Management accounting systems, perceived environmental uncertainty and organization structure: an empirical investigation. Accounting, Organizations and Society 9(1), 33-47.

Hair, J.F., Anderson, R.E., Tatham, R.L. and Black, W.C. (1998). Multivariate Data Analysis. 5th Edition. Prentice Hall International (UK) Ltd, London.

Hambrick, D.C. (2007) Upper echelons theory: an update. Academy of Management Review 32(2), 334-343.

Hambrick D.C. and Finkelstein, S. (1987) Managerial discretion: a bridge between polar views of organizations. Organizational Behavior 9, 369-406.

Hambrick D.C. and Fukutomi, G.D.S. (1991) The seasons of a CEO's tenure. Academy of Management Review 16(4), 719-742.

Hambrick, D.C. and Mason, P. (1984) Upper echelons: The organization as a reflection of its top managers. Academy of Management Review 9, 193-206.

Hambrick, D.C., Geletkancyz, M. and Fredrickson, J.W. (1993) Top executive commitment to the status quo: some tests of its determinants. Strategic Management Journal 14, 401-418. 
Harford, J. (1999) Corporate cash reserves and acquisitions. Journal of Finance 54, 1969-97.

Harford, J., Mansi, S.A. and Maxwell, W.F. (2008) Corporate governance and firm cash holdings in the US. Journal of Financial Economics 87, 535-555.

Herrmann, P. (2002) The influence of CEO characteristics on the international diversification of manufacturing firms: an empirical study in the United States. International Journal of Management 19(2), 279-292.

Jensen, M.C. (1986) Agency costs of free cash flow, corporate finance, and takeovers. American Economic Review 76(2), 323-329.

Jordan, J., Lowe, J. and Taylor, P. (1998) Strategy and financial policy in UK small firms. Journal of Business Finance and Accounting 25, 1-27.

Kitchell, S. (1997) CEO characteristics and technological innovativeness: a Canadian perspective. Canadian Journal of Administrative Sciences 14(2), 111-125.

Kor, Y. Y. (2006) Direct and interaction effects of top management team and board compositions on R\&D investment strategy. Strategic Management Journal 27(11), 1081-1099.

Kuan, T-H, Li, C-S. and Chu, S-H. (2011) Cash holdings and corporate governance in familycontrolled firms. Journal of Business Research 64, 757-764.

Kusnadi, Y. (2011) Do corporate governance mechanisms matter for cash holdings and firm value. Pacific-Basin Finance Journal, doi: 10.1016/j.pacfin.2011.04.002.

Malmendier, U. and Tate, G. (2005) Does overconfidence affect corporate investment? CEO overconfidence measures revisited. European Financial Management 11(5), 649-659.

Miller, D. (1991) Stale in the saddle: CEO tenure and the match between organization and environment. Management Science 37, 34-52.

Miller, D. and Shamsie, I. (2001) Learning across the life cycle: experimentation and performance among the Hollywood studio heads. Strategic Management Journal 22, 725-745. 
Miller, D., Kets de Vries, M.F.R. and Toulouse, J.M. (1982) Top executive locus of control and its relationship to strategy making, structure and environment. Academy of Management Journal 25(2), 237-253.

Milliken, F.J. (1987) Three types of perceived uncertainty about the environment: state, effect and response uncertainty. Academy of Management Review 12, 133-143.

Mulligan, C.B. (1997) Scale economies, the value of time, and the demand for money: longitudinal evidence for firms. Journal of Political Economy 105, 1061-1079.

Myers, S.C. and Majluf, N.S. (1984) Corporate financing and investment decisions when firms have information that investors do not have. Journal of Financial Economics 20, 293-315.

Norburn, D. and Birley, S. (1988) The top management team and corporate performance. Strategic Management Journal 9(3), 225-237.

Opler, T., Pinkowitz, L., Stulz, R. and Williamson, R. (1999) The determinants and implications of cash holdings. Journal of Financial Economics 52(1), 3-46.

Ozkan, A. and Ozkan, N. (2004) Corporate cash holdings: an empirical investigation of UK companies. Journal of Banking and Finance 28, 2103-2134.

Peeters, J. and Bogaert, J. (2005) Belgium in The practical guide to international corporate governance, FIR publications, 59-82

Rajan, R.G. and Zingales, L. (1995) What do we know about capital structure? Some evidence from international data. Journal of Finance 50, 1421-1460.

Ramirez, A. and Tadesse, S. (2009) Corporate cash holdings, uncertainty avoidance, and the multinationality of firms. International Business Review 18, 387-403.

Raskas, D.F., Hambrick, D.C. (1992) Multifunctional managerial development: A framework for evaluating the options. Organizational Dynamics 21(2), 4-17.

Richard, O.C., Wu, P. and Chadwick, K. (2009) The impact of entrepreneurial orientation on firm performance: the role of CEO position tenure and industry tenure. The International Journal of Human Resource Management 20(5), 1078-1095. 
Schroder, H.M., Driver, M.J. and Struefert, S. (1967) Human information processing. Holt, Rinehart \& Winston, New York.

Shakir, R. (2009) Examining the effect of leadership structure and CEO tenure on Malaysian property firm performance. Journal of Real Estate Literature 17(1), 47-62.

Subrahmanyam, A. (2007) Behavioural Finance: A review and synthesis. European Financial Management 14(1), 12-29.

Subramaniam, V., Tang, T.T., Yue, H. and Zhou, X. (2010) Firm structure and corporate cash holdings. Journal of Corporate Finance 17(3), 759-773.

Thomas, A. S, Litschert, R. J., Ramaswamy, K. (1991) The performance impact of strategy-manager coalignment: an empirical examination. Strategic Management Journal 12(7), 509-522.

Titman, S. and Wessels, R. (1988) The determinants of capital structure choice. Journal of Finance 43, $1-19$.

Van Gils, A. (2005) Management and governance in Dutch SMEs. European Management Journal 23(5), 583-589.

Wally, S., and Baum, J.R. (1994) Personal and structural determinants of strategic decision making. Academy of Management Journal 37, 932-956.

Walters, B.A., Kroll, M.J. and Wright, P. (2007) CEO tenure, board of directors, and acquisition performance. Journal of Business Research 60, 331-338.

Weinzimmer, L.G. (1997) Top management team correlates of organizational growth in a small business context: a comparative study. Journal of Small Business Management 35(3), 1-10.

Westphal, J.D. and Zajac, E.J. (1995) Who shall govern? CEO/board power, demographic similarity, and new director selection. Administrative Science Quarterly 40, 60-83.

Wiersema, M.G. and Bantel, K.A. (1992) Top management team demography and corporate strategic change. Academy of Management Journal 35, 91-121. 
Whited, T.M. (1992) Debt, liquidity constraints, and corporate investment: evidence from panel data. Journal of Finance 47, 1425-1460. 